\title{
THE DIFFICULTIES IN TEACHING VOCABULARY FACED BY THE ENGLISH TEACHERS AT MTS MADANI PAO-PAO MAKASSAR
}

\author{
Sulasri Ardiyanti. S \\ Universitas Islam Negeri Alauddin Makassar \\ sulasriardiyanti28@gmail.com \\ Kamsinah \\ Universitas Islam Negeri Alauddin Makassar \\ kamsinah@uin-alauddin.ac.id \\ Nurasik \\ Universitas Islam Negeri Alauddin Makassar \\ nurasik@uin-alauddin.ac.id \\ Abdul Muis Said \\ Universitas Islam Negeri Alauddin Makassar \\ abdulmuissaid@uin-alauddin.ac.id
}

\begin{abstract}
This research describes the difficulties in teaching vocabulary by the English teachers faced at MTs Madani Pao-Pao Makassar. It is conducted to know the difficulties in teaching vocabulary by the English teacher and also the factors that caused the difficulties in teaching vocabulary at MTs Madani Pao-Pao Makassar. The researcher uses descriptive qualitative to analyse the data. The researcher collects the data through observation and interview. The data are from the interview script. The researcher conducted the data by the English teachers as the subject. The teachers teaching in class 7 at MTs Madani PaoPao Makassar. The methods used by the researcher are collecting the data are conducted observation and interviews. The procedure for collecting data analysis is data reduction, data display, conclusion. Based on the class observation and interview, the researcher concludes the difficulties in teaching vocabulary at MTs Madani Pao-Pao Makassar and what are the factors that caused the difficulties for the teachers in teaching vocabulary at MTs Madani Pao-Pao Makassar. Based on the observation and interview, the researcher concluded that the difficulties in teaching vocabulary by the English teacher are classroom management; the teacher's difficulties in motivating the students; the teaching media is limited (especially textbooks); teacher's difficulties telling students for memorizing vocabulary. The factors that caused the difficulties in teaching vocabulary are laziness; lack of motivation; lack of vocabulary; students' lack of pronunciation; and students' lack of confident when learning English. The researcher suggested for the teachers to learn how to overcome their problems in the English especially vocabulary of the students, classroom management, and motivate the students for learning English because those were the main factors that affect teachers' difficulties in teaching vocabulary.
\end{abstract}

Keywords: Teachers difficulties, difficulties in teaching vocabulary, teaching vocabulary 


\section{INTRODUCTION}

Vocabulary is one of the important aspects in learning foreign languages. In order to communicate well in a foreign language, one should have enough vocabulary and knows how to use them correctly. Vocabulary is one of the elements that cannot be separated from language learning as it links the four language skills, namely: listening, speaking, reading and writing.

Vocabulary is also an important issue both for teachers and students in learning a foreign language. One's comprehension on a text either written or spoken will be highly depended on their level of vocabulary mastery. If they have sufficient numbers of vocabulary, they will easily comprehend the points either what writer delivers in a written text or messages delivered in spoken texts.

In fact, most of students have realized the importance of vocabulary in learning a foreign language. They also have strategies and ways to enhance the number of vocabulary they have. Usually, they carry a bilingual dictionary everywhere they go. As soon as they meet unfamiliar words, they will look up the new meaning of those words from the dictionary and write them on their notebooks. But after a while, they soon realize that this is not an effective way to improve the number of their vocabulary mastery. Most of the time, students feel bored and frustrated learning this way because they often forget the words as soon as they write them. Sometimes this condition might lead them to the conclusion that they have bad memorizations and this condition is concern to lead them to lose motivation.

The practice of teaching vocabulary which typically done in many schools also make students do not have creativity and initiatives. Mostly, students only ask teachers to provide the meaning of unfamiliar words found in a text. They wait for teachers to control the lesson by providing the meaning of the words and write them on their notebooks or to use them to complete their exercises. As a result, students can only use the word in the exact form they have taught and not knowing how to use them in different contexts in the real life communication.

\section{RESEARCH METHOD}

\section{Research Design}

This study is a qualitative research study since the research analysis detail information from participants to capture the whole pictures of phenomenon happened in natural condition. According to Moleong (2017) qualitative research is a study aimed at understanding the phenomenon of what happens by research subjects such as behavioral, perceptual, 
motivational, action, etc., holistically, and by way of description in the form of words a languages, in a special context that is natural and by utilizing various natural methods.

In addition, the steps on doing the qualitative research include how to collect, analyze, and interpret detail description on narrative and visual data or what so called by nonnumeric, so that the researcher can get a clear view of the natural phenomenon which becomes the interest of the researcher (Gay, Mills, \& Airasian, 2012).

\section{Subject of the Research}

The subject of this research is the English Teachers of MTs Madani Pao-Pao Makassar. The researcher choose first grade teacher of MTs Madani Pao-Pao Makassar due to vocabulary emphasized in teaching English the second grade students of MTs Madani Pao-Pao Makassar and also the third grade students.

\section{Instrument of the Research}

The istrument of this research is observation and interview. The researcher interviewed two until three teachers in MTs Madani Pao-Pao Makassar. The purpose of it is to know what difficulties that the teachers faced in teaching vocabulary in MTs Madani Pao-Pao Makassar. The purpose of observation is to describe everything related to the object of research, draw conclusion arranged into relevant report and can be useful as a learning of study material. While, the purpose of interview is to get the right information from reliable sources. Interview is conducted by submitting a number of questions from the interviewer to the informant.

\section{Procedure of Collecting Data}

According to Cresswell (1994:148), "The data collection step involve (a) setting the boundaries for the study, (b) collecting the information through observations, interviews, documents, and visual materials, and (c) establishing the protocol for recording information". It means that in data collection, the three steps used to collect the information are observation, interview, documentation and visual materials, and deciding the protocol of information record.

From the theory above, the techniques which researcher used in this study are as follow:

1. Observation

In this observation, the subject of observation are teachers on English vocabulary class. It focuses on the teachers difficulties in teaching vocabulary. Here, the researcher observed the teaching learning process on the efforts to know what are difficulties in teaching vocabulary.

The researcher observed the teachers while they teaching English vocabulary. The observation have purpose to find out what are the implementations of difficulties by the teachers and to get data on teaching learning process of teaching English vocabulary. The 
researcher want to know the difficulties faced by the English teachers in teaching vocabulary. The researcher collected the data on teachers' difficulties in teaching vocabulary by using interview.

\section{Interview}

The researcher added the document by conducting interview with the English teachers of MTs Madani Pao-Pao Makassar recorded using audio recording. The researcher asked the teachers about the difficulties faced by the English teachers in teaching vocabulary.

\section{Procedure of Data Analysis}

In analysing the data, the researcher used the descriptive method. To describe the teachers' difficulties in teaching Vocabulary. Data analysis would be conducted as follows:

\section{Data Reduction}

Data reduction would be done by summarizing field notes by separating main things relating to research problems, and then it would be arranged systematically to describe and to make easy the data searching if sometime it is needed anymore. Not all the obtained data of the research are important. It means that the important information must be taken and unimportant information must be ignored. In process of data reduction, the researcher would be select, focus and abstract the data in the field note. The data reduction is done during research activities. In this case, the researcher would be reduced information during the research activities if data is unimportant or do not support the data researchers needed.

\section{Data Display}

Data display is used to know the entire description of the result either in the form of matrix or coding. After it has conducted, the researcher is able to draw conclusion and verify it to be meaningful data it means describing data in the form of descriptive or narration. As the second component in analysing data, this technique is used arranging the information, description, or narration to draw conclusion. By presenting data, the researcher considered what the researcher should do. The researcher can analyse the other action based on her understanding.

3. Conclusion and Verification

To draw reasonable conclusion, it is conducted verification along with the research using member check, triangulation and audit trail, to guarantee result significance. In this study, conclusions would be drawn continuously throughout the course of study. Before the researcher write the conclusion, the researcher asked and interview teachers and headmaster for verification the data.

\section{FINDINGS AND DISCUSSION}




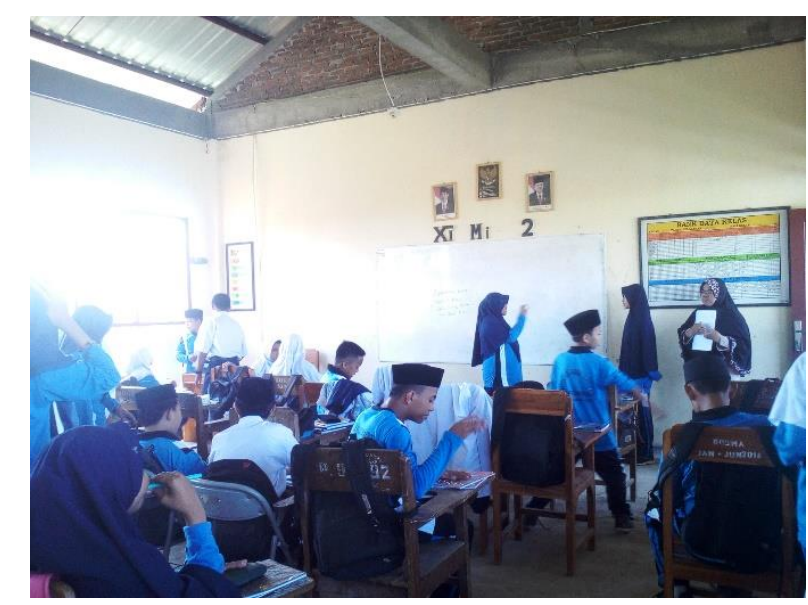

\section{Difficulties in Teaching Vocabulary}

\section{Classroom Management}

After conducting this research, the researcher found that sometimes a lot of teachers were less able to manage the class, this made the students less focus on the lessons. Based on the observations and interview made by the researcher, it was found that teacher's experiences difficulties in managing the class. The following pictures taken during observation were some of the events that showed when the teacher teaching in the classroom.

Figure 1: Teacher teaching in classroom

(The picture was taken by the researcher on 22 July 2019)

The picture showed that in the process of teaching, the students like to play with their friends during the lesson. The teacher found it difficult to control the class, so the class condition becomes less effective. Furthermore, this showed that teachers experience a situation called classroom management. The teacher said, "sometimes when we teach students it is difficult to control, even though it has been reminded many times but still does not want to hear instructions from the teacher".

\section{The Teacher's Difficulties in Motivating the Students}

The teachers have repeatedly provided motivated students, this can be seen when the researcher observation in the classroom the teacher motivating the students, there are only a few students who follow the instructions of their teacher and others are just busy playing and talking to themselves in a friend's seat. This was followed by a statement from the English teacher, the teacher said "We also sometimes find it difficult to motivate students to memorize more vocabulary because their names are also children, there are those who can be motivated and some who are very difficult to give motivation".

\section{The Teaching Media is Limited (Especially Textbooks)}


Based on observations, when the teacher teaching in the classroom, the teacher begins to have difficulties when they want to show the material to their students. The teacher can only show pictures (materials) in front of the class, and students who sit in the back row can only stand up and some students are willing to come forward only to see the material (pictures) that are shown by their teacher. This was followed by a statement from the English teacher, the teacher said "The difficulty is in terms of the media such as books, because when we teach automatically, we will provide printed books or textbooks to students so that students are also more enthusiastic and can directly see the material taught in the textbooks".

\section{Teacher's Difficulties Telling Students for Memorizing Vocabulary}

After conducting this research, the researcher found that teacher's difficulties telling students for memorizing vocabulary. This was also seen when the researcher conducted observations in the classroom, at the previous meeting the teacher had asked students to memorize 20 English vocabulary but when the teacher told students to memorize in front of the class, some students had memorized the vocabulary that had been instructed. By the teacher, the rest are still many students who do not memorize. So, the teacher told me to go back to memorize English vocabulary at home. However, this was very reasonable because English was not the mother tongue of the students and also they were in the process of studying more about English. The teacher said, "We also sometimes have difficulty motivating students to memorize more vocabulary". The statement above implied that they recognize that their language skill still needs to improve and also to improve their English language.

\section{The Factors that Cause the Difficulties for the Teachers in Teaching Vocabulary}

Some factors make it difficult for teachers to teach the vocabulary that researchers find when researching, which is below:

\section{Laziness}

Based on the observation, many students do not do repetition at home so that when teachers teach, students do not understand the learning content that is being given. The teacher also plays an important role in motivating students not to drag on laziness. Because today many students feel lazy if there is no motivation given by parents or teachers at school. The teacher said, "the second is because of laziness so they do not repeat or review the lessons at home".

\section{Lack of Motivation}

Motivation is one of the factors that can be said to be very able to create obstacles in learning because motivation provides effectiveness in learning activities. If there is no motivation in learning, this will definitely disrupt learning activities, and there would be no enthusiasm for learning. Motivation must always be given to students so that they are eager to 
learn English because after all, English is a language that is arguably mandatory to master because we have entered the era of globalization which means almost all things used English. Based on the interview, the teacher said, "the first factor is because they have no motivation, they are not aware of the importance of speaking English, the second is due to the lazy factor so they do not repeat or review the lessons at home".

\section{Lack of Vocabulary}

Based on observation and interview made by researcher on 7D class by Mrs. Rugayyah, the researcher found that the students have a lack of vocabulary. The researcher found that sometimes the students look confused when they found a strange word. The teacher said that "There are some difficulties for students who don't have a lot of vocabulary, automatically they don't understand the content of our learning".

This is a weakness that is very common in English. More students who speak Indonesian are very weak in mastering vocabulary. Students who have studied English for a long time must have a lot of unrecognized vocabulary. And who can communicate in English there must be vocabulary that has not been recognized. So this is the main problem of students in the problem of English language difficulties. The way to overcome this is to master a lot of vocabulary or vocabulary, often speak English or speak using English, and also be familiar in English and it should also be known that the key to speaking is to increase English vocabulary but when the researchers conducted observations and interviews at MTs Madani Pao-Pao Makassar there were still many students whose English vocabulary was lacking so that when teaching, and the teacher gave feedback to their students there were still many students who were still silent if asked to answer English questions from the teacher so the teacher has to explain again the material taught earlier this was said by one of the teachers who taught at the school, the teacher said, "the students don't do repetitions at home so they don't have vocabulary, they don't remember".

\section{Student's Lack of Pronunciation}

Based on observation and interview the teacher said "Children don't want to memorize vocabulary because they think vocabulary is not important, they also don't know how to read it and can't memorize the word" and "Students do not do repetitions at home so that their vocabulary is lack". Moreover, after conducting this research, the researcher found that the teacher was difficulties make the students saying pronunciation very well.

\section{The students' lack of Confident When Learning English}

The next factor that greatly makes teachers difficult to teach or instruct their students to memorize namely lack of interest and lack of confidence from students in learning English. 
Most of them feel afraid of being wrong or mistaken in using English in speaking. English is no longer a foreign language among academics and students alike, especially for students at school. However, even though English is the language of instruction in schools, there are still many students who hesitate to speak English. Not only lack of practice in speaking English but also, they seemed to be lazy to open their mouths and use various kinds of English conversation.

Based on observation and interview made by the researcher on Wednesday, July 192019 in the $7 \mathrm{D}$, the researcher found that some students have low confidence when they practice English. Based on the interview, the teacher said that "Sometimes there are also many students who are not confident when told to speak in English, they are afraid of being wrong”.

\section{CONCLUSION}

There were four difficulties in teaching vocabulary faced by the English teachers at MTs Madani Pao-Pao Makassar. Firstly, the teacher finds it difficult to control the class, so the class conditions become less effective, this situation called classroom management. Secondly, the teachers have repeatedly provided motivated students, this can be seen when the researcher observation in the classroom the teacher motivating the students. Thirdly, the lack of teaching media (specially textbooks). Fourthly, teacher's difficulties telling students for memorizing vocabulary because there are only a few students who follow the instructions of their teacher and others are just busy playing and talking to themselves in a friend's seat.

Based on observation, the factor that caused the difficulties in teaching vocabulary faced by the English teachers at MTs Madani Pao-Pao Makassar was not functioned well, students have laziness when teaching vocabulary in the classroom. Students lack of motivation this situation can we seen many students do not do repetition at home so that when teachers teach, students do not understand the learning content that is being given. Lack of vocabulary, lack in pronunciation, and students lack of confident when learning English make the teachers in teaching vocabulary.

\section{REFERENCES}

Alam, Rissovi Yustinia Sabda. (2009). Factors Causing Difficulties in Teaching Vocabulary to the Fifth Year Students of SD Negeri 8 Sragen. A Research Papaer. English Department, School of Teacher Training and Education. Universitas Muhammadiyah Surakarta. Retrieved on January 5, 2019 at eprints.ummsac.id/A320050061.pdf

Allen, Janet. (1999). Words, Words, Words: Teaching Vocabulary in Grades 2. Portland: Stenhouse Publisher. 
Gairns, R. \& Redman, S. (1986). Working with words: A guide to teaching and learning vocabulary. USA: Cambridge University Press.

H. Douglas Brown. (2007). Principles of Language Learning and Teaching, Fifth Edition New York, Pearson Education.

Harmer, Jeremy. (2001). English Language Teaching. Longman.

Hidayati, Suci. (2007). The Analysis of Students' Ability in Using Derivation Vocabulary. Unpublished Thesis

PrKoller, V., Harvey, S., Magnotta, M. (2010). Technology Based Learning Strategies. Prepared for U.S. Department of Labor Employment and Training Administration. English Teaching Forum.

Nina. (2004). Principles of Teaching English Vocabulary. Boston: Cengage Learning Products.

Oxford, R. (1990). Language Learning Strategies. Boston: Heinle \& Heinle Publishers.

Prastiyawati, Novi Ika. (2007). The Difficulties of Teaching Vocabulary Faced by the English Teacher at SDN 02 Yosowilangun Kidul Lumajang. A Thesis. Department of English Language Education, Faculty of Teacher Training and Education. Universitas Muhammadiyah Malang. Retrieved on January 5, 2019 at eprints.umm.ac.id/7122.pdf.

Rahmawati, Irma. (2015). Problems in Teaching Vocabulary to Young Learners at Aisyiyah Bustanul Athfal 01 Kindergarten Malang. A Thesis. Department of English Language Education, Faculty of Teacher Training and Education. 60 Universitas Muhammadiyah Malang. Retrieved on January 5, 2019 at eprints.umm.ac.id/25002.pdf.

Read, John. (2004). 7. Research in Teaching Vocabulary. Annual Review of Applied Linguistics. Princeton University.

Sugiyono. (2013). Metode Penelitian Kuantitatif, Kualitatif dan R\&D. Bandung: Alfabeta.

Thonbury, S. (2004). "Vocabulary in Teaching". Cambridge: MFT Press.

Thornbury, S. (2002). How to Teach Vocabulary. Essex: Longman. 